\title{
Luj przyjacielem Dorotki? Meandryczne metarefleksje o tęczowym języku z filologiczno-komparatystycznym przegięciem
}

Krzysztof Zabłocki

Uniwersytet Warszawski

\begin{abstract}
Czy istnieje polskijęzyk/slang LGBT? Tak, bez wątpienia, jednak wokót tego zagadnienia narosło niemało mitów i przekłamań. Warto zdać sobie sprawę, że mimo iż "tematyczne" zasoby leksykalne sa catkiem niemate, to wiele ze stów, określeń czy zwrotów albo nie jest już używanych, albo w ogóle istniało bądź istnieje jedynie teoretycznie, jak przypadku większości środowiskowych slangów także i w innych językach. Natomiast sporo określeń funkcjonujacych obecnie w języku polskiej "branży” wywodzi się z języka angielskiego, ale podobne zjawisko dotyczy również innych wspótczesnych języków. Niektóre z tych określeń otrzymały polskie odpowiedniki poprzez przekład lub adaptację do polskich schematów paradygmatyczno-syntagmatycznych. I warto dodać, że nowe, realnie używane określenia czy zwroty prawie nigdy nie powstaja na podstawie "stusznych" politycznie czy ideologicznie "dekretów". Nieuzasadniony jest też mit, że polskie słownictwo z zakresu tematyki LGBT, jak i w ogóle stownictwo dotyczące erotyki i seksu, jest bardzo ubogie - $i$ albo wulgarne, albo medyczne. Ten mit rozpowszechniany byt, między innymi, przez niektórych ttumaczy literatury, ale chodzi tu raczej o braki w ich osobniczej wiedzy językowo-obyczajowej, niż niedostatki języka.
\end{abstract}

Stowa kluczowe: język erotyczny [LGBTQ], dominacja języka angielskiego, język medyczny/wulgarny, bogactwo/ubóstwo polskiej terminologii, nietrafione przekłady/'zagubione w tłumaczeniu'

\section{Polski język LGBT - czy jest coś takiego?}

Czy istnieje język, czy slang polskiej społeczności LGBT, czy, jak kto woli, LGBTQ? I w ogóle jakiś sposób komunikowania się, komunikacyjny kod, hasła? Niewątpliwie taki kod i taki język istnieją, pewnie każdy zdołałby przywołać jakieś "tematyczne” słowa, czy zwroty, bądź przykłady niewerbalnej komunikacji. Ale myślę, że te kwestie należałoby rozważyć w nieco szerszym, kulturowo-lingwistycznym kontekście. A wypowiem się może przede wszystkim jako tłumacz, mając na koncie także przekłady literatury angloamerykańskiej i francuskiej of LGBT interest, jak to się ładnie po angielsku określa.

Jak wiemy choćby intuicyjnie, język jest odzwierciedleniem (a zarazem współtworzącym elementem) życia danej społeczności, jej zachowań i całościowej kultury ${ }^{1}$. Czasem potrzeba trochę czasu, by dana społeczność w ogóle taki język wypracowała, choćby w stadium początkowym. Wcześniej pojawiają się kody niewerbalne, dzieje się tak w każdym przypadku międzyludzkiej komunikacji, na przykład w relacjach niemowlęcia z jego otoczeniem. Ciekawym fenomenem może tu być przypadek chińskich gejów, których szczątkowe środowisko ukazane zostało w głośnym chińskim filmie sprzed ponad

1 Por. Halperin 2012: 347-349.

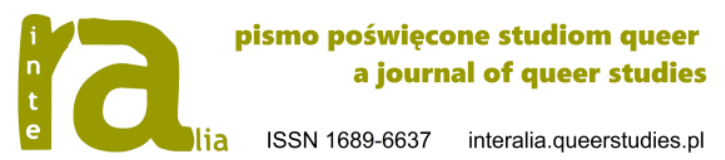


dwudziestu lat Dong gong xi gong (Wschodni Pałac, Zachodni Pałac)²; te "pałace" to określenia dwóch parkowych toalet w pobliżu słynnego pekińskiego placu Tian'anmen. Szczególnie interesujące jest to, że niektórzy z pekińskich gejów wyłapywanych w pekińskim odpowiedniku Parku Skaryszewskiego w ogóle nie znali słowa "homoseksualizm”, czy nie mieli na to chińskich odpowiedników. W sposób naturalny, genetyczny niejako, ciągnęło ich jednak do parkowych toalet, a (jak widać) geny zachowań homoerotycznych - i niewerbalne kody komunikacji - bywają ponadnarodowe ${ }^{3}$.

Ale wróćmy do języka. Jak już wspomniałem, język jest emanacją kultury. Zatem od razu, właśnie jako tłumacz, chciałbym „patriotycznie”, ale też całkiem na serio podkreślić, że język polski jest bytem niezwykle bogatym, plastycznym, fleksyjnym, z ogromną ilością arcyciekawych frazeologicznych konstrukcji. Bo też jest wyrazem bogatej kultury. Czy możemy jednak to samo powiedzieć o działce języka erotycznego, a konkretnie homoerotycznego, albo LGBT, używając obecnej terminologii?

Otóż i tak, i nie. Chciałbym jednak dodać, że nie całkiem zgadzam się z zakorzenionym wszechobecnie przekonaniem, że polski język erotyczny jest bardzo ubogi, a polskie słownictwo w tym zakresie jest albo medyczne, albo nazbyt wulgarne ${ }^{4}$. Myślę, że tak nie jest, a jeśli chodzi o słownictwo spod znaku LGBT, to sprawa jest nieco bardziej złożona.

I jeszcze jedna uwaga: dokonuje się niekiedy rozróżnienia pomiędzy językiem używanym przez osoby LGBT, w tym zwłaszcza gejów, ich środowiskowym idiolektem, a językiem czy słownictwem, który się do tych osób oraz ich spraw odnosi, lecz używanym niejako "na zewnątrz" tego środowiska; krótko mówiąc, językiem, którym się o osobach LGBT mówi. Mnie bardziej tu interesuje środowiskowy idiolekt, ale niekiedy trudno takie rozróżnienie wyraziście przeprowadzić, jako że te same słowa bywają używane "wewnątrz" i "na zewnątrz", a różni je jedynie intencja. Na przykład słowa "pedał" czy "ciota”: używane bywają "na zewnątrz" jako stygmatyzacja czy wyzwisko, aletakże "wewnątrz" - na przykład żartobliwie czy autoironicznie. Podobnie jest zresztą ze słownictwem dotyczącym mniejszości etnicznych czy osób z niepełnosprawnościami: słowa uważane obecnie za absolutnie nie do przyjęcia w użyciu standardowym (np. nigger, czarnuch, kulas czy ślepak) używane są przez osoby do tych grup należące $e^{5}$.

${ }^{2}$ Warto wspomnieć, że film ten został ostatecznie - pod względem technicznym - ukończony we Francji, gdzie też nieoficjalnie zaprezentowano go w 1997 roku na festiwalu w Cannes, zaś reżyser ZhangYuan został w Chinach ukarany aresztem domowym; do roku 1997 homoseksualizm traktowany był jako choroba, a zachowania sugerujące homoseksualizm (czy nawet ich filmową prezentację) kwalifikowano jakochuligaństwo. Zbadanie prawdopodobnego związku depenalizacji z tym filmem leży jednak poza sferą zainteresowań niniejszego tekstu.

3 Por. Halperin 2012.

4 Ta opinia, powtarzana od lat niczym mantra (por. Winnicka 2003; 3-9) była zresztą niejednokrotnie kontrowana (por. Lewinson 2002); kwestia "ubóstwa” bądź „bogactwa” polskiego języka erotycznego to zagadnienie na dłuższą dyskusję w innym miejscu.

${ }^{5}$ Por. Rodzoch-Malek (2012). W jaki sposób mówi się w polszczyźnie o homoseksualizmie i osobach homoseksualnych? Ta nieopublikowana praca doktorska zajmuje się przede wszystkim językiem używanym "na zewnątrz", ale niekiedy rozważa także użycie danego słowa w samym środowisku LGBT. 


\section{Rzut na tło angielskojęzyczne}

Ale spróbujmy zorientować się w sytuacji polskiego języka LGBT, porównując go ze słownictwem tematycznym w innych językach i biorąc za punkt wyjścia angielski (w tym wariant amerykański). Nie będę się jednak w tym miejscu zajmował usystematyzowanym dopiero niedawno brytyjskim "językiem" (gwarą/żargonem/slangiem) polari ${ }^{6}$, jako że pojęcie to obejmuje nie tylko miniony już, "sekretny" slang gejowski, ale także gwarę złodziejską, żargon półświatka prostytucji i narkomanów, gwarę marynarzy, elementy wschodniolondyńskiego cockneyu i pokrewnego z nim slangu rymowanego (rhyming slang), jak również slangu słów odwróconych. Z drugiej strony polari to także aluzyjny żargon z niektórych brytyjskich programów telewizyjnych zwłaszcza z lat sześćdziesiątych, jeszcze przed depenalizacją aktów homoseksualnych w 1967 roku. Nadto zawiera on domieszkę słów zapożyczonych z jidysz. Język (żargon, gwara, slang) polari (nazwa wywodząca się z włoskiego parlare) to zjawisko lingwistycznie i kulturowo fascynujące, możemy też zobaczyć w internecie przykłady jego użycia, czy wysłuchać ciekawych komentarzy Paula Bakera, profesora uniwersytetu Lancaster, autora słownika Fantabulosa (Baker 2002) i niejako kodyfikatora tej gwary. Oczywiście tylko część słów zaliczanych do polari przeszło do języka potocznego, nie wszystkie byłyby zrozumiałe także dla współczesnego brytyjskiego geja - podobnie jak niektóre polskie „środowiskowe” słowa, czy zwroty, obecnie już całkiem zapomniane, lub takie, które nigdy nie zaistniaływ językowym mainstreamie. Tak jest z każdą gwarą, każdym żargonem czy slangiem: korpus wyrażeń, niekiedy językowo arcyciekawych i twórczych, bywa bardzo obszerny, ale w faktycznym użyciu jest jedynie niewielka część tych słów i zwrotów. Mówił i pisał o tym zresztą Paul Baker, wspominając, że jedynie kilkadziesiąt słów polari zaistniało w szerszym kontekście (Baker 2002)ㄱ.

Przyjrzyjmy się zatem niektórym często używanym wyrażeniom angielskim i zastanówmy się, czy istnieją ich polskie odpowiedniki, albo czy w ogóle osobie z polskiego środowiska nieheteronormatywnego coś komunikują. Będzie to swego rodzaju wskazówka odnosząca się do sytuacji w polskim języku LGBT.

Może najpierw kilka słów niejako sztandarowych, zakreślających ramy tematu. Pozwolę sobie nieco szerzej skomentować trzy kanoniczne, moim zdaniem, terminy, żeby uzmysłowić ich wielowarstwowość, która umyka nie tylko przy ich użyciu w kontekście nieangielskim (albo przy użyciu ich odpowiedników w innych językach), ale niekiedy również native speakerom, także z samego środowiska gejowsko-lesbijskiego. Więc najpierw słowo gay, czyli "gej"w pisowni polskiej. Otóż jest ono przykładem pewnych nieporozumień, przekłamań,czy zawężenia pola znaczeń. Słowo to, wywodzące się

${ }^{6}$ Określenia gwara, żargon i slang używane są w lingwistyce niejako wymiennie, w pracach naukowych każdorazowo definiuje się te pojęcia dla potrzeb danego wywodu; tutaj chciałbym je potraktować jako właśnie swego rodzaju wymienniki.

${ }^{7}$ Dla przykładu wymienię tu kilka bardziej znanych słów w gwarze polari: dolly- atrakcyjna, atrakcyjny; bona - dobry; cod zły; naff - bez smaku, nijaki, a zarazem heteroseksualista; vada - spójrz; eek - twarz; lally- noga; nanti - nie, nic, nikt; omi,omee - mężczyzna; palone - kobieta; omi-palone - homoseksualista; riah - włosy. Tyle, że obecnie są one „znane” raczej tylko w środowisku lingwistów zajmujących się gwarą polari. 
ze starofrancuskiego gai, odnoszące się w pieśniach trubadurów do miłości dworskiej, radosnej, ale też niekiedy przekraczającej ustalone obyczajowe normy, miało podwójne znaczenie: nie tylko "wesoły”, „radosny”, lecz także "lubieżny”, „rozwiązły”. Z kolei w dziewiętnastowiecznej, wiktoriańskiej Anglii określenie gay w tym drugim znaczeniu odnoszono do heteroseksualnych żeńskich prostytutek (nazywanych mollies), a potem także do transwestytów, odwiedzających te same okolice lub te same domy publiczne - bądź to jako prostytutki, bądź to jako klienci. I stopniowo słowo to (podobnie jak i molly) zaczęło obejmować także tzw. „zniewieściałych” homoseksualistów, czy raczej „sodomitów”, bo termin homoseksualizm powstał, jak wiadomo, dopiero w drugiej połowie XIX wieku i z początku nie był zbyt szeroko używany. Ale dopiero w latach dwudziestych ubiegłego stulecia słowo gay stało się swego rodzaju kryptonimem homoseksualisty, zarówno w Anglii, jak i w Ameryce, i to w samych środowiskach homoseksualnych. Dla postronnej większości wciąż znaczyło tyle, co „wesoły, radosny" ${ }^{\prime \prime}$.

Tymczasem gdy zaraz po zamieszkach w czerwcu 1969 roku przed słynnym od tamtej chwili nowojorskim pubem Stonewall Inn (barze nie funkcjonującym jednak w pełni otwarcie jako miejsce "środowiskowe”, bo choć w Ameryce w większości stanów akty homoseksualne oficjalnie nie były penalizowane, to jednak homoseksualiści narażeni byli na nękanie policji, zwłaszcza w znanych szerzej miejscach spotkań) zaczął się w USA na dobre rozwijać ruch LGBT, słowo gay zostało obrane przez aktywistów jako swego rodzaju prowokacja. Podobnie było, dwadzieścia lat później, ze słowem queer: spokrewnione z niemieckim quer"; znaczące tyle, co "dziwny", zaczęło być używane w XIX wieku w Anglii jako eufemizm, żeby uniknąć niesympatycznego słowa sodomite. Po jakimś czasie nabrało odmiennego, a zarazem dwoistego znaczenia: z eufemizmu przerodziło się w słowo obraźliwe, klimatycznie zbliżone do polskiego „pedała”, a jednocześnie używane było w "mężolubczym” środowisku jako konotujące męskie - w przeciwieństwie do tzw. „zniewieściałych”- klimaty. Miał do słowa queer upodobanie na przykład Christopher Isherwood, autor Opowieści berlińskich, które posłużyły za kanwę wpierw Broadwayowskiego musicalu, a następnie słynnego filmu Kabaret; Isherwood był też oczywiście autorem Samotnego mężczyzny (Isherwood 2012) ${ }^{10}$. Natomiast pod koniec lat osiemdziesiątych, w okresie buntu przeciw bezczynności amerykańskiej administracji w obliczu epidemii AIDS, powstała radykalna organizacja Queer Nation, a słowo queer w nazwie miało stanowić kolejną buntowniczą prowokację i zastąpić zwietrzałe już nieco pod względem siły ekspresji słowo gay. Wkrótce potem rozwinęła się także akademicka dyscyplina Queer Studies (zaś sama teoretyczna

\footnotetext{
${ }^{8}$ Pamiętam z autopsji rymowanki z lat 1960. (w zarówno polskich, jak i brytyjskich podręcznikach do angielskiego dla szkół podstawowych), gdzie opisywani w nich chłopcy byli niemal zawsze określani jako gay, bo przecież wzorcowy podręcznikowy chłopiec z natury swej jest wesoły; jednak pamiętam także (chyba w roku 1980) rozmowę z leciwą Amerykanką, która wybierając się do Francji, ekscytowała się bliskim nawiedzeniem gay Paris, czyli, w jej mniemaniu, zawsze rozpustnego Paryża.

9 Por. przedrostek w słowie Querstrasse - ulica "w poprzek", przecznica.

10 Por. Isherwood, Christopher and His Kind (2012). Tamże: Vidal, Gore. Introduction. Isherwood używał tego słowa już od późnych lat 1940. - mówił, że "heteroseksualiści wzdrygają się, gdy je słyszą" (It makes heterosexuals wince). Por. także Hogan, S., Hudson, L., Completely Queer (1998 : 464).
} 
refleksja była [i wciąż jest określana] jako Queer Theory), będąca niejako latoroślą Gender Studies. Co ciekawe, Teresa de Lauretis, obecnie profesorka emerita historii świadomości Uniwersytetu Kalifornijskiego w Santa Cruz, której przypisuje się autorstwo pojęcia Queer Theory (po raz pierwszy zastosowanego w 1990 roku), w ogóle ponoć nie słyszała o organizacji Queer Nation, i użyła tego określenia jako swoistego umbrella term, bardziej pojemnego, a zarazem bardziej wyrazistego od tradycyjnego Gay and Lesbian Studies. ${ }^{11}$ Określenie queer natomiast zaczęło mieć stopniowo coraz szersze znaczenie i zastosowanie, obejmując nie tylko nieheteronormatywną seksualność, ale także wszelką kontrkulturowość i offowość. Wystarczy dodać, że przed mniej więcej dziesięcioma laty w warszawskich klubach gejowskich i gay-friendly dostępne było mikroskopijnego formatu pisemko o tytule "Queer City", zamieszczające informacje o offowych eventach kulturalnych, zwłaszcza tzw. "tematycznych".

I wreszcie, żeby dopełnić triadę: trzecie "kanoniczne”, moim zdaniem, słowo, czyli camp, w języku polskim niekiedy pisane przez "k". I otóż dziwi, że słowo to jest tak mało w Polsce znane - na przykład wśród studentów uniwersyteckich kierunków humanistycznych, o czym zaświadczam z wieloletniej autopsji w murach akademii. Tyle że w polskim (w przeciwieństwie do angielskiego) określenie to nie weszło jeszcze do języka potocznego. Gdy przedstawiamy je osobom niezaznajomionym z tematyką, wystarczy po prostu wspomnieć, że jest to kategoria kulturowo-estetyczna, której dominantą jest ostentacyjne (choć czasem niezamierzone) estetyczno-behawioralne przerysowanie bądź kicz, z elementami ironii, prowokacji, czy perwersji. Ale camp jest w istocie pojęciem tak pojemnym, iż jak wiadomonie zdołała go uściślić Susan Sontag w swoim słynnym eseju z 1964 roku (Sontag 2017), więc tym bardziej nie sposób go doprecyzować w kilku słowach.

Określenie to, wywodzące się z francuskiego se camper - stać dumnie w wyniosłej pozie (por. polskie arch. „trzymać pola” $)^{12}$, zaczęto stosować w kontekście dumnie noszących się dandysów z przełomu XIX i XX wieku. W XX wieku słowo camp zaczęło być używane w odniesieniu do przerysowanych („przegiętych”) zachowań części osób homoseksualnych czy też elementów ludycznej „kultury homoseksualnej"; uosobieniem campu stały się drag-queens. Obecnie camp jest jedną z kluczowych kategorii kulturoznawstwa i odnosi się zarówno do estetyki, jak i do wszelkich zachowań czy działań scenicznych, estradowych czy performatywnych, cechujących się elementami kiczu i prowokacyjnym

11 Por. Hogan, S., Hudson, L., ibid., s.467.

12 Bardziej wyczerpująca prezentacja etymologii i użycia tego słowa i różnych jego postaci nie jest tu oczywiście możliwa. Etymologia to w ogóle kwestia nieraz niejednoznaczna: np.. słowo „pedał " można po prostu wywieść od "pederasty"(jako „naturalne" i nośne zdrobnienie), ale jednocześnie może być uważane za polski odpowiednik francuskiego pédale (pédé), skądinąd podobnie deminutywu od pédéraste. Prof. Michał Głowiński uważa, że "pedał” ma właśnie pochodzenie francuskie, co moim zdaniem jest możliwe (choć nie do udowodnienia), a przypuszczalnie także słowo "pederasta" zaistniało w języku polskim poprzez język francuski właśnie. Ciekawe jest również, że wśród niektórych polskich gejów „po studiach", nieświadomych greckiego źródłosłowu paiderastia(pais, paidos[dziecko, chłopiec] + erastes [miłośnik]), pokutuje niekiedy interpretacja, że słowo „pederasta” wywodzi się od łacińskiej nazwy stopy (pes, pedis) i ma zatem oznaczać "coś niskiego". Pewnie przez analogię do słowa pedicure. Niestety nikt już nie uczy się łaciny (nie wspominając o elementach greki) i można by przytoczyć cytat z poematu Alexandra Pope'a: A little learning is a dangerous thing... 
przerysowaniem. W Polsce świetnym przykładem campu jest osoba i artystyczny profil Violetty Villas, a za przykład campu w architekturze (z perspektywy współczesnej) uważany jest przez niektórych warszawski Pałac Kultury. Zresztą po krótkim wprowadzeniu wspomniani studenci spontanicznie podają te przykłady. Tak więc camp to nie tylko drag-queens, wedle dość rozpowszechnionego mniemania (wśród tych, którzy znają określenie camp, rzecz jasna), jednak dla estetyki i kultury LGBT jest to słowo absolutnie kluczowe.

Mamy więc trzy ważne angielskie słowa, używane w wielu językach w wersji albo oryginalnej, albo nieco przekształconej. I już ta kanoniczna triada pokazuje, że angielski jest w kontekście LGBT językiem absolutnie i niepodzielnie dominującym, a wszelkie inne języki - nawet tak znaczące jak francuski czy niemiecki - po prostu nie mogą sięz angielskim równać (mimo iż de facto zarówno gay, jak i camp, wywodzą się z francuskiego, zaś queer ma germański źródłosłów). Spójrzmy teraz na kilka innych często używanych angielskich określeń, i zobaczmy, czy w kontekście polskim zachowują kształt oryginalny, czy też mają jakieś odpowiedniki.

Choćby wspomniana już drag queen. Otóż drag w gwarze polari oznacza tyle, co ubiór właściwy dla płci przeciwnej, a według jednej z wielu etymologicznych interpretacji drag wywodzi się z niemieckiego tragen, czyli "nieść, nosić". Zatem drag-queen to królowa niewieściego stroju, a może "ciotka w przebraniu"... I oto w języku LGBT mielibyśmy kolejne angielskie słowo o germańskich korzeniach. Coming out i outing - pierwsze określenie używane jest najczęściej w wersji oryginalnej, ale mamy też wdzięczne polskie "wyjście z szafy”, względnie, znacznie rzadsze, "wychodzenie z ukrycia”, bądź "ujawnianie się". Najwierniejszym odpowiednikiem byłoby „wyjście ze schowka”, czy jakiegoś innego sekretnego pomieszczenia, ale przyjęła się "szafa”, bo czego się nie robi dla dobrego brzmienia. Outing pozostaje już tylko w oryginale, ale często stosuje się czasownik "wyautować". Inna rzecz, że oba te pojęcia są nierzadko mylone, warto więc pamiętać, że outingu nie dokonuje się samemu; to nie to samo, co coming out, ale ujawnienie osoby skrywającej swoją nieheteronormatywną orientację, a która zarazem bywa homofobem. ${ }^{13}$

Ze słowników terminów LGBT (Fosberry 2005; Baker 2004) wybieram kilka innych często używanych angielskich określeń: $A C / D C$ (dosłownie prąd zmienny/prąd stały, ale też znana grupa rockowa) czyli biseksualista; to określenie było w języku angielskim obecne już na przełomie lat sześćdziesiątych i siedemdziesiątych. Wygląda na to, że australijska grupa (powstała w 1973 roku) wzięła swoją nazwę od tego skrótu, mając na uwadze właśnie jego podwójne znaczenie; przypomina to trochę przypadek Freddie'go Mercury, którego zespół obrał nazwę Queen, a queen to nie tylko królowa, czyli coś "the very best, refined, exquisite", jak przewrotnie tłumaczył sam Freddie, lecz także klimatyczny odpowiednik polskiego określenia "ciota”. Bareback - to słowo od dawna już funkcjonuje także i w polskim środowisku LGBT, ale jako seks bez prezerwatywy, a nie jazda na oklep, choć to poniekąd trafne zestawienie. Wymienię jeszcze kilka innych pełnych wdzięku określeń - niektóre mają

${ }^{13}$ Do polskich odpowiedników coming outu powrócę w dalszej części tego tekstu. 
polskie odpowiedniki, ale jednocześnie są świetnie zrozumiałe w wersji oryginalnej, i często używane w tej właśnie postaci. No więc alfabetycznie, ale tylko kilka z nich, rzecz jasna: bang (i gang bang), blowjob, bondage, boner, bottom (tu jako nie tyle niewinna pupa, co osoba pasywna), butch i butch lesbian, butt plug. "C": chaser (czyli wielbiciel misiów, w żargonie polskim nieraz przybiera to słowo formę "szaser"), cock ring, colour code, confirmed bachelor (czyli zatwardziały kawaler - był to także kryptonim homoseksualisty), cottage ${ }^{14}$, czyli publiczna toaleta, zwłaszcza parkowa, a zarazem pikieta (z kolei cottaging to wystawanie, czy łowy na pikiecie lub po prostu seks "na miejscu”), cross-dressing, cruising, czyli znów „pikietowanie”, cunt, tu nie tyle cip(k)a, co kobieta żywiąca niechęć do gejów, oraz cut, czyli obrzezany (jak i uncut) i zatem cock alias dick, rzecz jasna. I jeszcze parę przykładów, bo większej ilości haseł nie sposób tu przytoczyć: daddy i sugar daddy, darkroom, dildo, discipline (wymierzanie cielesnej kary, czyli spanking (lanie), lub, jak kto woli, CP, corporal punishment, czyli bardziej formalnie "kary cielesne"), dresscode, dyke (lesba, taki właśnie klimat, nie lesbijka, ale lesba właśnie), fag, faggot, a także fag hag (czyli kobieta, która lubi przestawać z gejami, ich wielbicielka/przyjaciółka), fairy (dość archaiczne określenie, klimatycznie „pedzio”), family, czyli środowisko, a więc "branża", femme, czyli odwrotność butch lesbian, i piękne friend of Dorothy, czyli przyjaciel Dorotki, adorator bohaterki filmu The Wizard of $\mathrm{Oz}$, granej przez Judy Garland ${ }^{15}$ - kryptonim geja, coś z epoki i klimatów „zatwardziałego kawalera”. I już na zakończenie tej listy, rezygnując z kolejności alfabetycznej, a wedle kaprysu pamięci: rice queen - wielbiciel Azjatów (czyli ras „żółtych”), curry queen (per analogiam wielbiciel Hindusów), tea-room (znów toaleta, zwłaszcza parkowa), threesome, czyli trójkąt, twink, czyli młodziak, sling, skórzany lub gumowy hamak, zwłaszcza w gejowskim klubie, ułatwiający przybranie odpowiedniej pozycji do seksu, gaydar (gejdar), gejowski radar, czyli zdolność rozpoznawiania gejów, glory hole, dziura w drewnianej bądź dyktowej ściance między kabinami w publicznej toalecie, vanilla sex, czyli seks po bożemu. I tak dalej, pięknie i niemal bez końca.

Gdy spojrzymy na słownictwo francuskie i niemieckie, to także uderza przytłaczająca dominacja angielskiego. Owszem, jest kilka słów niemieckich, powiedzmy "wyjątkowych”, znanych także poza lokalnym terenem - choćby oczywiście schwul, o dość niejasnej etymologii (pochodzące rzekomo od schwül w standardowym niemieckim, czyli duszny, parny, co miało nawiązywać do gęstego klimatu w (krypto)gejowskich berlińskich lokalach, szczególnie licznych w okresie Republiki Weimarskiej), niby odpowiednik pedała, ale klimatycznie jest teraz słowem politycznie poprawnym, właściwie bardziej odpowiednikiem gay. Słowo to weszło do mainstreamu historii współczesnej, gdy przed kilkunastu

\footnotetext{
${ }^{14}$ Określenie to, używane w UK w kontekście seksualnym od początku XX wieku, wzięło się oczywiście stąd, iż toalety parkowe wyglądały (a nadal jest ich sporo) jak "słodkie" chatki; podobne przybytki mieliśmy i mamy w Polsce, tyle że w naszym kraju przekształcane bywają obecnie w kawiarnie.

${ }^{15}$ Warto wspomnieć, że wydarzeniom w (i przed) Stonewall Inn przypisuje się pośredni związek z uroczystościami pogrzebowymi Judy Garland (1922-69), które odbyły się w piątek, 27 czerwca 1969 w samym New York City (msza) i w stanie Nowy Jork (pochówek). W uroczystościach uczestniczyło ok. 20 tysięcy osób, w tym szacuje się, że niemałą część z nich stanowili geje; wielużałobników miało wieczorem odwiedzić Stonewall Inn, a w dodatku z powodu pogrzebu atmosfera w "środowisku” była tego dnia pełna gorących emocji. Kwestia, czy rzeczywiście pogrzeb Judy Garland miał jakiś związek z zamieszkami wokół baru Stonewall wciąż jest dyskutowana, jednak ten domniemany związek przybrał już teraz postać trwałej legendy. Por. Duberman 1995, Miller 1995, Zabłocki 2009.
} 
laty Klaus Wowereit, socjaldemokratyczny kandydat na burmistrza Berlina, wypowiedział w czasie kampanii wyborczej słynne zdanie (w kontekście tego miasta chyba równie znane jak Ich bin ein Berliner Johna Kennedy'ego i zapewne do niego nawiązujące): Ich bin schwul und das ist auch gut so! No i Tunte - czyli ciota. Pikieta to Klappe (słowo oznacza też klimatycznie "wyro"), i mamy także Klappensex; używa się również słowa cruising. I może jeszcze Devot, czyli slave, albo masochista.

Inne niemieckie słowa "tematyczne” są bardziej prozaiczne, nie mają szczególnej nośności czy wdzięku, jak przytoczone słowa angielskie. Jeśli chodzi o język francuski, todobrym źródłem terminologii mógł być założony w 1979 roku miesięcznik, a potem tygodnik "Gai Pied" ("gejowska stopa", także "gejowska frajda", albo "gejowski obieżyświat, bywalec", ale można traktować tę nazwę jako homofon guêpier, co znaczy gniazdo szerszeni). Tytuł pisma, który w tym ostatnim odczytaniu miał sugerować drażnienie zastałej świadomości, zaproponował Michel Foucault. Jako kolejne źródło posłużyć może następca "Gai Pied", czyli "Tetu” („uparciuch", bezczelny, zadziorny śmiały). Pikieta to la tasse, a pikietować to faire les tasses. Tasse (filiżanka) to też uliczna lub parkowa toaleta. (Ale także vespasienne, w tym przypadku na ogół blaszana - naszym odpowiednikiem mógłby być "grzybek". Słowo vespasienne jest niekoniecznie "gejowskie", ale w jakimś sensie takim się stało, podobnie jak i grzybek) ${ }^{16}$. Często używane są francuskie odpowiedniki pikiety i pikietowania, czyli drague (m.in. połów oraz podryw), oraz draguer i lieu(x) de (la) drague. Oczywiście pédé i homo, a inne odnoszą się do erotyki niekoniecznie homoseksualnej - na przykład bander ${ }^{17}$ (dosłownie "napinać [się]", czyli mieć erekcję), czy enculer - "dupczyć", "rżnąć", ale dosłownie mieć stosunek analny. Tante, czyli standardowa ciota, i wzmocniona wersja tantouze. Warto wspomnieć jeszcze baba cool - podstarzały hipis. „Lecący" na młodych chłopców, rzecz jasna, czyli posthipisowski sugar daddy...

W rosyjskim mamy "goluboj" (niby od niebieskich strojów dla chłopców (czyli "chłopcy, którzy lubią chłopców"), albo też od niebieskiej krwi homoseksualnych arystokratów w carskiej Rosji, i jeszcze golub i golubok. Także pedik i gomik. I też nie ma tu fajerwerków. W Polsce w miarę znane są również czeskie buzerant i hiszpańskie marica, maricón.

\section{Polski - jak ma się w tym odnaleźć?}

W sferze LGBT angielski rządzi zatem niepodzielnie, przyczyniła się do tego nie tylko pozycja Stanów Zjednoczonych jako czołowego światowego mocarstwa i rola języka angielskiego jako współczesnego, realnego „esperanto", ale także wiodąca rola aktywistów, naukowców, czy twórców tego

${ }^{16}$ Oprócz najsłynniejszego polskiego "grzybka” na Placu Trzech Krzyży w Warszawie (postawionego w 1892 roku przez Compagnie Nouvelle des châlets de commodité pour la France et l'Etranger, a rozebranego w 2005; www.metrowarszawa.pl, historia-warszawskie pikiety, 08.02.2017) było też - na ogół do lat 1960. - całkiem sporo innych "grzybków" w różnych miejscach stolicy (a także i w niektórych innych miastach).

${ }^{17}$ Słowo bander zauroczyło Milana Kunderę, sławnego czeskiego pisarza osiadłego we Francji i piszącego w późniejszym okresie po francusku. Seks to jeden z istotnych wątków jego twórczości: bawiło go to, że po francusku erekcję określa się czasownikiem używanym w stronie czynnej. Por. Kundera 1991. 
kraju w przecieraniu szlaków LGBT. Tak więc trudno się dziwić, że nie tylko w języku polskim zadomowiło się sporo anglojęzycznych słów i zwrotów, czasem nieco "udomowionych", a czasem pod postacią przekładów, czy to dosłownych, czy to nieco "zaadaptowanych”. Czy powinniśmy z tego powodu rozdzierać przysłowiowe szaty? W końcu warto sobie uświadomić, że każde bez wyjątku słowo, i to w jakimkolwiek kontekście, ma jakiś źródłosłów, i czasem "obce" słowa brzmią nieporównanie "naturalniej" i "normalniej”, niż ich odpowiedniki utworzone na bazie dotychczas istniejącego korpusu językowego, co na ogół jest postrzegane jako coś „pozytywnego”. Język, jak też wiadomo, nie istnieje w abstrakcji, ale jest tworem/bytem społecznym i politycznym - wystarczy tu przywołać choćby kontrowersje dotyczące żeńskich końcówek w języku polskim. Pomyślmy, na przykład, czy zadowoleni bylibyśmy ze słów "dalekowidzenie" zamiast "telewizora", albo "gościnica" zamiast "szpitala"? Owszem, przyjął się "samochód", a w niemieckim mamy "Fernsehen", czyli swojskie słowo na "telewizor". Więc "co brzmi lepiej" to jedynie kwestia przyzwyczajenia, ale dlaczego korzeń słowiański ma być zawsze lepszy od łacińskiego? Bez mała dwadzieścia lat temu tygodnik „Polityka" zorganizował rodzaj konkursu na polskie odpowiedniki obcych (głownie angielskich) słów i wyrażeń, które zaczęły być używane w Polsce po 1989 roku. Większość propozycji brzmiała dość niezręcznie, żeby nie powiedzieć groteskowo, niektóre świadczyły jednak o wyczuciu językowym bądź poczuciu humoru pomysłodawców; gdy natomiast dano je do oceny kilku profesorom językoznawstwa, to ich wskazania były niekiedy (moim zdaniem) na twory najbardziej niezręczne z niezręcznych, przy jednoczesnym odrzuceniu (jako niezgodnych z lingwistycznym paradygmatem albo duchem języka polskiego) tych, które „dla zwykłego ucha” (czyli mojego) brzmiały najlepiej i miały najwięcej wdzięku ${ }^{18}$.

Przywołajmy też kilka słów wprowadzonych w latach 60. do języka polskiego na podstawie zaleceń Komitetu Językoznawstwa PAN, takich jak na przykład "publikatory”, które miały zastąpić pojawiające się wtedy dopiero słowo "media”, które na dodatek miało kojarzyć się z wywoływaniem duchów, ale w tym drugim wypadku, co dziwne, nie traktowano go już jako "obce”. Czy ktoś słowa "publikatory" używa? Podobnie zadekretowano, by zamiast "Indie” używać wersji „India”, a zamiast Hindus - Indus. Tu były obszerne lingwistyczno-historyczno-polityczne uzasadnienia, zresztą całkiem sensowne, tyle że India czy Indus po prostu nie brzmiało dla polskiego ucha dobrze. Co zresztą ciekawe, słowo "Indus" było niekiedy używane przed wojną - na przykład w książce Podróż do Indyj (1933) autorstwa Ferdynanda Goetla. Kończąc ten wywód chciałbym tylko dodać, że próby wprowadzania nowych słów „dekretem" niemal zawsze zawodzą. Na każdy argument znaleźć można kontrargument, jak to ma

18 "Polityka” 2000: „Spolszcz to sam, czyli znajdź polski odpowiednik”. Konkurs ten nawiązywał do ustawy o języku polskim (pierwsza wersja została uchwalona w 1999, a potem nastąpiły kolejne nowelizacje), która miała na celu „ochronę czystości polszczyzny". Kilka przykładowych propozycji: moderator - dyskuter, mądry tato; e-mail - epesza, o-mam; dżojstik gierek, grączka; chat (czat) - egadka, kliklotki; software - krzemózg, móżdżyna; cheerleaderka - parederka. (Ta ostatnia propozycja otrzymała jedną z nagród; dla mnie jednak słowo to brzmi okropnie, tak pod względem asocjacji [derka], jak i eufonii [nieprzyjemna twardość]. No i ukazana jest tu cała absurdalność owych licytacji, które słowo jest niby bardziej polskie: wszak „parada” wywodzi się z łacińskiego parare (m.in. przygotowywać, układać/porzadkować, przyozdabiać). 
miejsce w przypadku wspomnianej powyżej dyskusji o żeńskich końcówkach ${ }^{19}$. Ale to już temat na deliberacje w innym miejscu.

Z wyżej wspomnianych względów trochę mnie bawią, a trochę niepokoją, próby jeśli nie "dekretowania", to choćby intensywnego sugerowania "właściwych" słów czy określeń spod znaku LGBT. Rozważmy wspomniany wcześniej zwrot coming out ${ }^{20}{ }^{2}$ którego użycie zadomowiło się już w języku polskim na tyle, że jest obecnie powszechnie zrozumiały, a nadto ma pełen wdzięku odpowiednik "wychodzenie z szafy" (kilka lat temu odbył się w Warszawie przed pomnikiem Kopernika happening z autentyczną szafą, z której ochotnicy mogli publicznie „wychodzić" ${ }^{21}$. Cały zwrot to jednak coming out of the closet, czyli wychodzenie z (sekretnego) schowka, ale "szafa” brzmi nieporównanie lepiej. Otóż zalecane są zwroty „wychodzenie z ukrycia”, albo "ujawnianie się”. Natomiast outing miałby być zastąpiony „wyciąganiem z ukrycia”. Wydaje się jednak, że jeśli słowa czy zwroty mają mieć nośność, to nie zapewni im tego "słuszność", ale właśnie wdzięk, eufonia, zaczepienie się w już istniejącej leksykalno-frazeologicznej siatce. A tego te zalecane (bo mają być politycznie "słuszniejsze") polskie odpowiedniki nie mają.

Podobnie z inną propozycją, a mianowicie z polskim odpowiednikiem słowa queer. Proponuje się słowo „odmieniec", sugerując że queer to zawłaszczone słowo negatywne. Zapewne inspiracją był tu Piotr Odmieniec Włast - nowa tożsamość Marii Komornickiej. Otóż przy całym szacunku dla tej niezwykłej postaci, jej legendy oraz ikoniczności, dla mojego ucha negatywnie brzmi właśnie „odmieniec", sugerując dziwaka, osobę nieprzystosowaną, bądź z jakąś dysfunkcją psychiczną. Queer natomiast stracił już właściwie (przede wszystkim w języku angielskim) dawne negatywne konotacje. Zadomowił się już na dobre i po prostu brzmi lepiej22.

Inne z kolei proponowane słowo to "prostytut", które miałoby zastąpić "męską prostytutkę" - ale kto tak w ogóle by powiedział? I jeszcze jeden przykład - pride. Warto w tym miejscu przywołać opinię Jerzego Krzyszpienia, proponującego oczywiście słowo „duma":

Zastanawiające jest, że w polskich tekstach często nie tłumaczy się nazw emancypacyjnych imprez lub świąt, które zawierają słowo pride 'duma' mające głosić przeciwieństwo wstydu. W konsekwencji przytaczanie tych nazw tylko w oryginale

\footnotetext{
${ }^{19}$ Ostatnio na ten tematwypowiadał się Michał Rusinek (Rusinek 2018).

20 Por. Basiuk 2010.

${ }^{21}$ Określenia „wychodzić z szafy” użyła w tytule swej książki Anna Laszuk (1969-2012), dziennikarka i działaczka LGBT. Por. Laszuk 2007.

22 Por. Krzyszpień 2010. Na temat słowa „odmieniec” miałem publiczną (oczywiście przyjazną) wymianę opinii z Karolem Radziszewskim (podczas jednej z konferencji związanych z naszym projektem) - Karol Radziszewski jest tego słowa zwolennikiem. To poniekąd wskazuje na niejednoznaczność odbioru języka LGBT także wśród osób aktywnie ze środowiskiem LGBT związanych.
} 
angielskim sprowadza całą ideę do zwykłego frazesu pochodzącego z obcej kultury. (Krzyszpień 2010:142)

Trudno zgodzić się z jego propozycją. Obecnie - za sprawą czy to globalizmu, czy to podróży i uczestnictwa w zagranicznych eventach, czy na przykład popularnego brytyjskiego filmu Pride (choć polski tytuł to Dumni i wściekli), słowo pride przyjęło się w Polsce w wersji oryginalnej - i dobrze. Coroczna warszawska Parada Równości ma obecnie drugą nazwę w postaci Warsaw Pride, co tworzy klimat, a w dodatku „brzmi”. „Duma gejowska i lesbijska, duma gejów i lesbijek, Dzień Dumy Gejowskiej i Lesbijskiej, Dzień Dumy Gejów i Lesbijek" - brzmiałoby to zbyt pompatycznie i dla mojego ucha to nie to ${ }^{23}$.

Kolejna sprawa: jak już wspomniałem, stawia się zarzut, że polska terminologia dotycząca spraw seksu w ogóle, a spraw LGBT w szczególności, jest albo medyczna, albo wulgarna. Jako przykład mogłaby posłużyć wydana przed dziesięciu laty Radość seksu gejowskiego (Silverstein, Picano 2009) ${ }^{24}$; terminologia użyta w tej książce była szeroko komentowana w prasie i na forach LGBT. Chodzi o to, że nawet recenzenci gejowscy zarzucali jej niekiedy zbytnią dosadność i wulgarność języka ${ }^{25}$. Ale co my w tej książce mamy? Otóż pojawiają się słowa takie jak ch..., rżn..., je..., dziura, itp. Tymczasem słowa te w wersji oryginalnej nie szokują w ogóle. Sprawa ma się bowiem tak, że wulgaryzmy, obscena angielskie w ogóle przestały native speakerów szokować; można by nawet powiedzieć, że straciły swą niegdysiejszą moc. Dlatego też nie zawsze uzasadnione bywają zarzuty, że polskie napisy w anglojęzycznych filmach nie oddają ostrości dialogów w języku oryginalnym. Rzecz w tym, że z reguły powinny być o stopień (umowny) słabsze. Natomiast wulgaryzmy polskie wciąż swoją moc zachowują, mimo często bardzo prozaicznych i niewinnych ich pierwotnych desygnatów (np. słowo ch... wywodzi się od choiny, słowo kur.... od prasłowiańskich słów określających kurę i koguta [a nie od łacińskiego curvus/curva/curvum, jak się powszechnie uważa], słowo d... znaczyło kiedyś dziupla; o niewinnym kutasie - wisiorku - nawet nie warto wspominać). Dlatego słowo $f .$. nie powinno być tłumaczone jako pier..., lecz raczej jako piep.... I tak też mamy z tą książką - słowa zostały przełożone zbyt dosłownie, tymczasem moderacja ich polskiej mocy zdecydowanie pomogłaby odzwierciedlić klimat i moc oryginału.

Jakie konkluzje możemy zatem wyciągnąć z wyżej przedstawionych przykładów? Z językiem polskim nie jest tak źle, jak mogłoby się wydawać - angielski rządzi niepodzielnie, ale określeń w języku polskim (choćby właśnie zapożyczonych z angielskiego, które stały się słowami polskimi) jest niemało;

\footnotetext{
${ }^{23}$ Por. Krzyszpień 2010.

${ }^{24}$ Charles Silverstein, Felice Picano, przeł. Dariusz Kołaczkowski. 2009. Radość seksu gejowskiego. Warszawa: Wydawnictwo Czarna Owca. Książka ukazała się w USA w 1977 roku jako The Joy of Gay Sex, autorstwa Edmunda White'a i Charlesa Silversteina. W późniejszych wydaniach, na skutek nieporozumień co do zmian w jej treści i formie graficznej, Edmund White, jeden z czołowych obecnie pisarzy amerykańskich, wycofał swoje nazwisko; jako współautora zastąpił go Felice Picano. Historia edycji tej książki, ciekawa sama w sobie, to jednak odrębny temat.

25 Por. Szot, Wojciech, Zawód większy niż wzwód, www.homiki.pl., dostęp od 03.07.2009.
} 
faktem jest jednak, że sporo ciekawych bądź urokliwych określeń czy wyrażeń albo już dawno wypadło z użycia, albo nie było one de facto powszechnie używane. Któż użyje dziś słów takich jak górnik (czyli aktyw, top), albo parówa (pasyw, bottom; Gorgol 1990)? Ze słownictwem jest tak, że rodzi się spontanicznie, nie można niczego zadekretować, a słowa tworzone "celowo", ze świadomym zamierzeniem, z reguły się nie przyjmują. Podobnie jak wiele spośród określeń napotykanych w słownikach slangu, żargonu czy gwary istniało lub istnieje bardziej teoretycznie niż realnie. Tak też jest zresztą z językiem angielskim, francuskim czy niemieckim - słowa będące w rzeczywistym użyciu, w przeszłości czy obecnie, wcale nie były i nie są tak liczne, a większość z określeń wymienianych w tematycznych słownikach to słowa istniejące jedynie "teoretycznie". Poza tym wiele z tych słów (w tym wulgaryzmów) nie odnosi się jedynie do kontekstu homoseksualnego. Uważam, że najlepszym tekstowym źródłem polskiego słownictwa LGBT, i to tego używanego rzeczywiście, były wychodzące od początku lat 1990. do pierwszej dekady lat 2000. nieistniejące już niestety pisma gejowskie, zwłaszcza najdłużej wydawane poznańskie "Inaczej", gdańskie "Filo" i „Facet”, czy warszawskie "Okey" oraz "MEN", a później „Nowy MEN". Zwłaszcza "Inaczej”, które było pismem poważnym, a zarazem erotycznym. Oczywiście funkcje tych pism przejął internet, nic jednak nie zastąpi bogactwa językowego, które te pisma oferowały, choć trzeba docenić istniejące dziś portale Queer.pl, czy homiki.pl - ten drugi jest niestety obecnie dormant („uśpiony"), ale liczne jego teksty są nadal w internecie dostępne.

Przekładając pozycje z literatury of $L G B T$ interest z angielskiego czy francuskiego nie napotykałem zatem na problemy „nie do przezwyciężenia” związane z "nędzą" polskiego języka erotycznego czy dotyczącego sensu stricto seksu, co tak chętnie rozgłaszali i rozgłaszają niektórzy tłumacze (i niektóre tłumaczki), biorący owe książki na warsztat. Te problemy wynikać mogąraczej z ich niepełnej znajomości polskiego języka erotyczno-seksualnego, i to tego z rejestrów "niższych”, języka z zakresu obyczajowości zwłaszcza nie(hetero)normatywnej, nieraz mocnego i obscenicznego, ale może przede wszystkim z braku obeznania z samą tą obyczajowością, co dla niektórych translatorów płci obojga może właśnie okazywać się przeszkodą nie do przezwyciężenia ${ }^{26}$.

${ }^{26}$ Dość pechowe są pod tym względem przekłady powieści znanego brytyjskiego pisarza Alana Hollinghursta. Odkryłem szereg irytujących (choć zarazem zabawnych) "kiksów” zarówno w Klubie Korynckim (oryginał: The Swimming-Pool Library), jak i Spadajacej gwieździe (The Folding Star), i w wypadku tej pierwszej pozycji wskazałem owe błędy wydawcy (obiecano, że zostaną poprawione w kolejnym wydaniu, co pewnie nastąpi jedynie wtedy, gdy Hollinghurst otrzyma Nobla, co nie wydaje się w przypadku tego wybitnego pisarza niemożliwe), natomiast z Obcym dzieckiem (The Stranger's Child) rozprawił się może nazbyt brutalnie w swej recenzji Jacek Dehnel ("Gazeta Wyborcza”, 9.10.2012). Oto kilka przykładów (dotyczących nie tylko terminologii, ale także nieznajomości realiów i klimatów):

1. Hollingurst, The Swimming-Pool Library (s. 6 oryginału, s.15 wersji polskiej): narrator odwiedza publiczną toaletę w Hyde Parku, schodzi na dół po schodkach i widzi stojących przy pisuarach mężczyzn, masturbujących się, bądź wyczekujących na "okazję" - w wersji polskiej mamy „kilkunastu” zmiast "kilku”, mimo iż w oryginale jest słowo several. Nie wiem, czy było to błędne rozumienie słowa (mało prawdopodobne), czy nieuwaga, czy może celowy zamiar „podkręcenia” narracji, co jest częstym grzechem tłumaczy; z pewnością jednak, gdyby tłumaczka była kiedyś (choćby w przebraniu jako "obserwator uczestniczący") na takiej pikiecie (podobnie jak Katarzyna Kozyra odwiedziła w Budapeszcie męską saunę), to wiedziałaby, że tych mężczyzn w skromnym parkowym przybytku nie mogło być "kilkunastu".

W innym miejscu (s. 64 i s. 99) tytuł pisma (krypto)pornograficznego "The Spanking Times" został przełożony jako „Brutalny seks". Otóż o ile spanking i „kary cielesne” to znane powszechnie narodowe upodobanie Brytyjczyków z wieloletnią szkolną tradycją (obecnie w związku z Brexitem niektórzy brytyjscy posłowie domagają się powrotu takich kar do szkół) i "miękkopornograficzne” pisemko "The Spanking Times” (zresztą niekoniecznie homoerotyczne) mogło się z 
I jeszcze jedno: język LGBT, „wewnętrzny” lub „zewnętrzny” to nie tylko odrębne słownictwo, ale może nawet bardziej użycie „zwykłych”, "heteroseksualnych" słów w innym znaczeniu (np. ciotka, koleżanka). To także specyficzna nieraz frazeologia czy budowa zdań, albo inne końcówki wskazujące na rodzaj gramatyczny. Jeżeli zaś chodzi o polski język "sekretny", o jakieś tajne kody bądź słowa-hasła znane jedynie wtajemniczonym ze środowiska, to chyba o czymś takim mówić raczej trudno.

Choć może tutaj dwa słowa dotyczące tytułu powyższych rozważań: o ile (dla mojego ucha tłumacza) chyba najbardziej klimatycznie anglosaskim określeniem jest wspomniany już eufemistyczny krypto$\operatorname{nim}$ a friend of Dorothy (zawierający całe bogactwo kulturowych tropów i odniesień), to z kolei kwintesencją polskości może być słowo luj (przaśne już samym swym brzmieniem) - łobuz, bandyta, zakapior, menel, sutener, ale także (swoiście polski kryptonim) heteroseksualista zadający się z homoseksualistami, czy to ulegając ich pożądaniu, a zarazem własnej nieodpartej potrzebie seksualnego rozładowania, czy to w celu finansowych korzyści bądź po prostu kradzieży lub rozboju. Bo przecież z homoseksualistami mógł się zadawać jedynie zakapior bądź menel, współtworząc tego środowiska „kryminogenność" - to z kolei ulubione słowo PRL-owskich strażników socjalistyczno-drobnomieszczańskiej moralności i ustrojowego porządku.

\section{Podziękowania}

Artykuł powstał w ramach projektu "Cruising the 1970s: Unearthing Pre-HIV/AIDS Queer Sexual Cultures" (CRUSEV) finansowanego ze środków HERA Joint Research Programme 3 "Uses of the Past" przy współfinansowaniu ze strony AHRC, BMBF via DLR-PT, MINECO, NCN oraz Komisji Europejskiej w ramach programu Horizon 2020.

powodzeniem półlegalnie ukazywać w czasach penalizacji aktów homoseksualnych, to „Brutalny seks”, oczywiście z tytułem angielskim, w tamtych czasach już z pewnością nie, pomijając to, że spanking nie ma wiele wspólnego z „brutalnym seksem”, cokolwiek by się pod tą mało sensowną polską wersją rozumiało. Jest tu jeszcze mały żart w postaci nawiązania do tytułu najważniejszego ongi (i nieco napuszonego) brytyjskiego dziennika "The Times”, czy w ogóle tytułu „poważnej gazety": w wersji polskiej można by to oddać jako np. „Trybuna klapsów”...

2. W The Folding Star (s. 336 oryginału, s.318 wersji polskiej) narrator przybliżył twarz do pośladków nagiego młodego kochanka, a konkretnie do samego ich środka, i w oryginale breathed on it (czyli musnął go oddechem), natomiast w wersji polskiej mamy "obwąchałem go". Wdzięczne słowo pucker(czyli ów „środek”), nasuwające na myśl ściągnięte wargi nadąsanego chłopca, przełożone jest jako odbyt, niczym z podręcznika proktologii. A zatem muśnięcie oddechem ("nadąsanego") rowka przemienia się w wąchanie odbytu, poetycka erotyka w skatologię - czyli istotnie mamy tu do czynienia z językiem medyczno-wulgarnym, co jakby współgrało ze wspomnianymi utyskiwaniami co do "nędzy polszczyzny".

3. Nic jednak nie przebije casusu z polskim przekładem powieści Philadelphia Christophera Davisa (Davis 1995), napisanej na podstawie scenariusza głośnego filmu, gdzie pojawiające się co parę stron słowo "heteryk" (czyli polski odpowiednik straight) zostało (przed skierowaniem książki do druku, już po ostatecznej redakcji) „poprawione” wszędzie przez korektora (korektorkę?) na "heretyk". Tłumacz (mój znajomy) o mało nie przypłacił tego zawałem (bo w końcu to pewnie jego obarczono tym potwornym lapsusem ), ale denerwował się niepotrzebnie: otóż nawet i teraz spora część "badanych" przeze mnie studentów kierunków humanistycznych najlepszej uczelni w Polsce też nie zna słowa "heteryk".Tak przy okazji: uważam, że właśnie studenci (z uwagi na ich intelektualną "mobilność") są tą grupą społeczną, która najlepiej wskazuje na poziom świadomości językowej danego społeczeństwa. 


\section{Bibliografia}

Baker, Paul. 2004. Fantabulosa. A Dictionary of Polari and Gay Slang. London and New York: Continuum.

Basiuk, Tomasz. 2010. Coming out po polsku. W: (red.) Kochanowski, Jacek, Abramowicz, Marta, Biedroń, Robert. Queer Studies. Podręcznik kursu. Warszawa: Kampania Przeciw Homofobii.

Davis, Christopher. 1995. Filadelfia. Tłum. Andrzej Zasadziński. Warszawa: Alfa.

Dehnel, Jacek. „Obce dziecko” po polskiemu. W: „Gazeta Wyborcza” 9.10.2012.

Duberman, Martin. 1994. Stonewall. New York: Plume.

Fosberry, Charles T. 2005. Gay Slang. London: Arson Books.

Gorgol, Tadeusz. 1990. Zakazana miłość. Warszawa: Instytut Wydawniczy Związków Zawodowych.

Halperin, David M. 2012. How to be Gay. Cambridge, Mass., London: The Belknap Press of Harvard University Press.

Hogan, Steve, Hudson, Lee. 1998. Completely Queer. The Gay and Lesbian Encyclopedia. New York: Henry Holt and Company

Hollinghurst, Alan. 1995. The Folding Star. London: Vintage.

Hollinghurst, Alan. 1993. Klub Koryncki. Tłum. Maria Olejniczak-Skarsgård. Warszawa: Czytelnik.

Hollinghurst, Alan. Spadająca gwiazda. 1997. Tłum. Magda Białoń-Chalecka. Wrocław:

Wydawnictwo Dolnośląskie.

Hollinghurst, Alan. 1988. The Swimming-Pool Library. London: Vintage.

Isherwood, Christopher. 2012. Christopher and His Kind. (Ze wstępem Gore'a Vidala). London: Vintage.

Isherwood, Christopher. 1998. Goodbye to Berlin. London: Vintage Books.

Kostrzewa, Yga, Minałto, Michał, Pietras, Marcin, Szot, Wojciech, Teodorczyk, Marcin, Tomasik, Krzysztof, Zabłocki, Krzysztof. 2009. HomoWarszawa. Przewodnik kulturalno-historyczny. Warszawa: Abiekt.pl, Otwarte Forum, Lambda Warszawa.

Krzyszpień, Jerzy. 2010. Język i emancypacja LGBT: uwagi praktyczne. W: (red.) Kochanowski, Jacek, Abramowicz, Marta, Biedroń, Robert. Queer Studies. Podręcznik kursu. Warszawa: Kampania Przeciw Homofobii.

Krzyszpień, Jerzy. 2018. Wychodzimy z ukrycia. Kraków: Korporacja Ha!Art.

Kundera, Milan. 1991. Słownik. W: Sztuka powieści. Tłum. Marek Bieńczyk. Warszawa: Państwowy Instytut Wydawniczy.

Laszuk, Anna. 2007. Dziewczyny, wyjdźcie z szafy! Warszawa: Fundacja Lorga.

Lewinson, Jacek. 1999. Stownik seksualizmów polskich. Warszawa: Książka i Wiedza.

Lewinson, Jacek. Erotyzm, nie obscena. Chcę udowodnić, że mamy język seksualny, ale zostat zapomniany. Rozmowa z Iwoną Konarską. W: „Przegląd” 2.04.2002.

Miller, Neil. 1995. Out of the Past. Gay and Lesbian History from 1869 to the Present. London: Vintage.

„Polityka” (nr 23-32/2000): Spolszcz to sam, czyli znajdź polski odpowiednik. 
Popławska, Marta. 2017. "Parę razy tu zgrzeszyłem. Warszawskie pikiety - miejsca na szybki seks”. http://metrowarszawa.gazeta.pl/metrowarszawa/56,141636,21254334,warszawskiepikiety.html; dostęp: 08.02.2017.

Rodzoch-Malek, Jagoda. 2012. W jaki sposób mówi się w polszczyźnie o homoseksualizmie i osobach homoseksualnych? Analiza leksykalna na podstawie danych leksykograficznyh i tekstowych.

Nieopublikowana praca doktorska, Zakład Leksykologii, Stylistyki Teoretycznej i Kultury Języka Polskiego.

Silverstein, Charles, Picano, Felice. 2009. Radość seksu gejowskiego. Tłum. Dariusz Kołaczkowski. Warszawa: Wydawnictwo Czarna Owca.

Sontag, Susan. 2012. Zapiski o kampie. W: Przeciw interpretacji i inne eseje. Tłum. Dariusz Żukowski. Warszawa: Karakter

Stępniak, Klemens. Współpraca: Zbigniew Podgórzec. Słownik tajemnych gwar przestępczych. Londyn: Wydawnictwo Puls.

Szot, Wojciech. 2009. Zawód większy niż wzwód. W: „Homiki.pl” 3.07.2009.

http://homiki.pl/index.php/2009/07/zawd-wikszy-ni-wzwd.

Tuftanka, Urfe. 1993. Zakazane wyrazy. Słownik sprośności iwulgaryzmów. Warszawa: Wydawnictwo "O".

Winnicka, Ewa. 2003. Dlaczego nie możemy o tym rozmawiać... W: „Polityka” 39, s. 3-9.

Witkowski, Michał. 2005. Lubiewo. Kraków: Korporacja Ha!Art.

Zabłocki, Krzysztof. 2008. Campowy długopis Watęsy. W: „Zielono i w poprzek” 2, s.9-11.

Zabłocki, Krzysztof. 2009. Bar Bastylia. W: „Polityka” 27.06.2009, s. 62-64.

\section{A homothug and a friend of Dorothy? Meandering metareflections on "Rainbow Language" with a philological and comparative bent...}

Is there such an entity as Polish LGBT language and slang? Undoubtedly there is, but various myths and misconceptions have arisen in relation to this topic. The Polish LGBT lexical corpus is certainly not negligible, though many of the words and expressions either fell out of use or they existed and exist only in theory, as is the case of many jargons shared by specific communities also in other languages. Moreover, many words and expressions functioning now within the Polish 'family' derive from English, as is also the case of some other contemporary languages. Some of these expressions have acquired Polish equivalents - either via translation or by being adapted to the Polish paradigmatic and syntagmatic structures. It should be noted that new words and expressions rarely happen to be the result of 'politically (ideologically) correct' decisions or demands. There is also a widespread, if unfounded, myth that Polish LGBT vocabulary, and generally the lexis relating to sex and eroticism, is rather limited, and that it is either vulgar or medical. This myth is propagated, among others, by some literary translators, but this felt lack is due to idiosyncratic lacunae in their lexical and cultural awareness rather than objective linguistic deprivation.

Keywords: erotic (LGBTQ) vocabulary, predominance of English, medical/vulgar, richness/penury of Polish erotic vocabulary, 'lost in translation' 